\title{
Pedigree and mating system analyses in a western larch (Larix occidentalis Nutt.) experimental population
}

\author{
Tomas Funda, Charles C. Chen, Cherdsak LiewlaksaneEyanawin, Ahmed M.A. Kenawy, \\ Yousry A. EL-KASSABY*
}

Department of Forest Sciences, 2424 Main Mall, University of British Columbia, Vancouver, British Columbia, V6T 1Z4, Canada

(Received 12 May 2008; accepted 11 July 2008)

Keywords:

western larch /

Larix occidentalis /

seed orchards /

mating system /

paternity analysis /

SSR /

gene flow
Mots-clés : mélèze occidental / Larix occidentalis / verger à graines / système de croisement / analyse de paternité / microsatellite / flux de gènes

\begin{abstract}
-The mating pattern and gene flow in a western larch (Larix occidentalis Nutt.) experimental population was studied with the aid of microsatellite markers and a combination of paternity-mating system analysis. The commonly difficult to assess, male gametic contribution was determined with $95 \%$ confidence and its impact on genetic gain and diversity was determined.

- Male fertility success rate ranged between 0 and $11 \%$. Male reproductive output parental imbalance was observed with $50 \%$ of the pollen being produced by the top 5\% of males while the lower $39 \%$ males only produced $10 \%$ of the pollen.

- A significant difference was observed between male effective population size (genetic diversity) estimates from paternity assignment compared to those based on population's census number (21 vs. 41); however, this difference did not affect estimates of genetic gain.

- A total of 221 full-fib families were identified (sample size range: 1-8) and were nested among the studied 14 seed-donors.

- A combination of paternity-mating system analysis is recommended to provide a better insight into seed orchards' mating dynamics. While pollen flow tends to inflate mating system's outcrossing rate, the paternity analysis effectively determined the rate and magnitude of contamination across receptive females.
\end{abstract}

Résumé - Analyse de paternité et du mode de croisement dans une population expérimentale de mélèze occidental (Larix occidentalis Nutt.)

- Les modes de croisement et les flux de gènes dans une population expérimentale de mélèze occidental (Larix occidentalis Nutt.) ont été étudiés à l'aide de marqueurs microsatellites et d'une analyse combinée de paternité et du système de reproduction. La contribution gamétique mâle - communément difficile à estimer - a été déterminée avec un seuil de confiance de $95 \%$ et son impact sur le gain génétique et la diversité a été déterminé.

- Le taux de succès reproductif mâle était compris entre 0 et $11 \%$. Un déséquilibre dans la contribution des parents mâles a été observé avec la production de $50 \%$ du pollen par $5 \%$ des pères alors que $39 \%$ d'entre eux ne contribuaient que pour seulement $10 \%$ du pollen.

- Une différence significative a été observée entre la taille efficace de la population mâle (diversité génétique) estimée par la recherche de paternité et celle basée sur les effectifs recensés de la population (21 vs. 41); cependant, cette différence n'affecte pas l'estimation du gain génétique.

- 221 familles de plein-frères ont été identifiées (effectifs entre 1 et 8), regroupées parmi les 14 arbresmères étudiés.

- La combinaison d'une analyse de paternité et du système de reproduction est recommandée pour étudier de manière approfondie la dynamique de croisement en vergers à graines. Tandis que les flux de pollen tendent à augmenter le taux d'inter-croisements, l'analyse de paternité détermine de manière effective le taux et l'amplitude de contamination des arbres-mères.

\footnotetext{
*Corresponding author: y.el-kassaby@ubc.ca
} 


\section{INTRODUCTION}

The Larix genus is the only deciduous conifer in the Pinaceae family comprising of 10 recognized species that encircle the Northern Hemisphere with variable economic and ecological importance throughout their range (Schmidt, 1995; Schmidt and McDonald, 1995). Western larch (Larix occidentalis Nutt.) is commonly found in valley bottoms and along the steep slopes of montane forests in the Upper Columbia River Basin of western North America (Jaquish and ElKassaby, 1998). While it is generally considered to be among the largest of North America's larches, it is the most shade intolerant conifer in its region. However, it attains its large size through rapid growth during early age, thus outgrowing its associates until it gets overtopped by other slow growing, shade tolerant species (Schmidt et al., 1976). The importance of western larch has been recognized not only for its commercial wood products, but also for its outstanding non-timber values such as aesthetics, wildlife habitat, outdoor recreation and watershed protection (Schmidt and Shearer, 1995).

Population genetic studies of western larch and its related species began as early as 1980s where measures of genetic variation (Fins and Seeb, 1986; Jaquish and El-Kassaby, 1998; Khasa et al., 2000; Semerikov and Lascoux, 1999; Semerikov and Matveev, 1995; Semerikov et al., 1999) and mating system (El-Kassaby and Jaquish, 1996) were reported to aid the species' gene resource management, including selective breeding and conservation. During the mid-1990s, the British Columbia Ministry of Forests and Range embarked on western larch genetic improvement program starting with selection of superior phenotypes, breeding and testing, and the establishment of production populations (seed orchards) for seed production (Jaquish et al., 1995). Seed orchards are experimental populations where selected parents are replicated by grafting on root-stocks and planted in a random fashion to minimize inbreeding (Faulkner, 1975). The genetic quality of the resultant seed crops is of importance since seeds are the conduct for passing breeders' efforts to the forests. Parental male (pollen) and female (seed) gametic contribution, level of inbreeding, and the extent of pollen migration (contamination) from outside sources, all determine the genetic quality of these seed crops (Stoehr et al., 2004). The availability of highly informative DNA markers such as microsatellites (Vendramin and Hansen 2005) and the development of sophisticated pedigree reconstruction methods (Jones and Ardren, 2003) made it possible to reconstruct the genetic relationships among seeds/individuals derived from natural open-pollination and classify them into their respective FS and HS families.

In the present study, we provide an example of the utilization of microsatellite markers in estimating parental gametic contributions and its impact on genetic gain and diversity calculations, inbreeding, and the extent of pollen migration using a combination of pedigree reconstruction-mating system analysis.

\section{MATERIALS AND METHODS}

\subsection{Plant material, DNA extraction and fingerprinting}

Needle samples from 41 parents representing the entire experimental population (seed orchard) were sampled along with windpollinated seed from a subset of 14 parents $(N=40 /$ parent $)$ were collected for DNA fingerprinting. The experimental population is one of two genetically distinct (no common parents) western larch seed orchards established by British Columbia Ministry of Forests and Range to provide genetically improved seed to the Nelson $(<1300 \mathrm{~m})$ and East Kootenay (800-1500 m) seed production units (Forest Genetics Council of BC, 2008). The orchards are located near Vernon, B.C., Canada (the Kalamalka Forestry Centre: altitude 480 m, latitude $50^{\circ} 14^{\prime} \mathrm{N}$, longitude $119^{\circ} 16^{\prime} \mathrm{E}$ ) and are separated by a road $(\approx 8 \mathrm{~m}$ wide) and a row of black cottonwood trees on one side. Parents (clones and ramets within clones) were arranged on the orchard's grid following the permutated neighbourhood design (Bell and Fletcher, 1978).

The material for this study was provided by the East Kootenay seed orchard that was established in 1989 from phenotypic selection within south-eastern British Columbia's natural populations, thus it is assumed that the parents are unrelated and non-inbred. The orchard population consists of 1280 ramets representing the 41 clones (average: 31 ramets/clone). The orchard's parental breeding values (height at age 60) were predicted from two series of 10-year-old progeny test trials located within the parental natural range (B. Jaquish, BC Ministry of Forests, personal communications).

Total DNA from either needles (parents) or germinating embryos (progeny $(1 \mathrm{~cm})$ ) was isolated using a modified CTAB (cetyltrimethylammonium bromide) method (Doyle and Doyle, 1990; Khasa et al., 2000). All samples, parents and seeds (half-sib families), were genotyped using a set of 12 microsatellite markers for pedigree reconstruction and mating system analyses. Three of the studied SSR markers used were developed and their Mendelian mode of inheritance was demonstrated by Khasa et al. (2000). The remaining nine markers (see Tab. I) were developed by Chen et al. (2008) and their Mendelian mode of inheritance is illustrated using the sampled 14 half-sib families.

Polymerase chain reaction (PCR) amplifications were carried out in $10 \mu \mathrm{L}$ total volumes with $1 \times$ Taq buffer $(10 \mathrm{mM}$ Tris, $1.5 \mathrm{mM}$ $\mathrm{MgCl}_{2}, 50 \mathrm{mM} \mathrm{KCl}, \mathrm{pH}$ 8.3) (Roche, Laval, Quebec) using a GeneAmp 9700 thermal cycler (Perkin-Elmer, Foster City, CA). Each reaction was composed of $50 \mathrm{ng}$ of total genomic DNA, $0.3 \mathrm{pmol}$ M13 IRD-labeled primer, 0.5 pmol each of forward and reverse primers, 0.1 unit of Taq DNA polymerase (Roche) and $0.2 \mathrm{mM}$ of dNTP. Western larch DNA samples were amplified with a program as follows: 5 min of pre-incubation at $94{ }^{\circ} \mathrm{C}$; followed by 25 cycles of $1 \mathrm{~min}$ at $94{ }^{\circ} \mathrm{C}, 1 \mathrm{~min}$ at respective annealing temperature (see Tab. I, Chen et al., 2008) and $1 \mathrm{~min}$ of extension at $72{ }^{\circ} \mathrm{C}$; and $3 \mathrm{~min}$ of incubation at $72{ }^{\circ} \mathrm{C}$ as the final step of extension. PCR reaction products were then denatured, and $2 \mu \mathrm{L}$ of atop dye were added to each PCR reaction ( $100 \%$ formamide, $1 \mathrm{mg} / \mathrm{mL}$ pararosaniline basic red 9) before electrophoresis, which was conducted using Li-Cor 4200 (Li-Cor Inc., Lincoln, NE) automated sequencer with 5\% polyacrylamide (Long Ranger ${ }^{\mathrm{TM}}$ ) gels. No multiplexing was attempted during this study.

\subsection{Mode of inheritance of microsatellite loci}

The wind-pollinated seed collected from the 14 parents (half-sibs with a sample size of 40 seeds per parent) were used to illustrate 
Table I. Mode of inheritance for western larch microsatellite loci using wind-pollinated seed from 14 parents. $G$-test for the goodness-of-fit to the 1:1 segregation ratio for pooled data $\left(G_{P}\right)$ and test of heterogeneity among multiple parents sharing the same heterozygous genotype $\left(G_{H}\right)$.

\begin{tabular}{|c|c|c|c|c|c|}
\hline \multirow{2}{*}{ Locus/Primer } & \multirow{2}{*}{ Mother tree genotype } & \multirow{2}{*}{ Number of trees } & \multirow{2}{*}{ Observed segregation } & \multicolumn{2}{|c|}{$G$-test } \\
\hline & & & & $G_{P}$ & $G_{H}$ \\
\hline UBCLXtet_1-22 & $202 / 240$ & 2 & $52: 72$ & 03.23 & 03.25 \\
\hline UBCLXtet_21 & $142 / 158$ & 2 & $85: 49$ & $09.79 * *$ & $10.54 * *$ \\
\hline UBCLXtet_32 & $188 / 196$ & 5 & $218: 156$ & $10.32 * *$ & $20.86^{* * *}$ \\
\hline \multirow{2}{*}{ UBCLXtet_2-12 } & Null/250 & 2 & $40: 31$ & 01.14 & $09.42 * *$ \\
\hline & Null/260 & 2 & $58: 69$ & 00.95 & 01.76 \\
\hline \multirow[t]{2}{*}{ UBCLXtet_2-11 } & $152 / 164$ & 2 & $76: 45$ & $08.03 * *$ & $08.31 *$ \\
\hline & $152 / 170$ & 3 & $147: 87$ & $15.55^{* * *}$ & $15.6^{* *}$ \\
\hline UBCLXA4_1 & $196 / 206$ & 3 & $79: 114$ & $06.38^{*}$ & $23.51 * * *$ \\
\hline \multirow[t]{2}{*}{ UBCLXdi_21 } & Null/315 & 5 & $124: 142$ & 01.21 & 01.44 \\
\hline & Null/335 & 3 & $75: 104$ & $04.72 *$ & $09.15^{*}$ \\
\hline UBCLXdi_16 & Null/240 & 2 & $32: 23$ & 01.48 & 01.48 \\
\hline
\end{tabular}

* Significance at $P<0.05$; ** $0.005<P<0.05$; *** $P<0.005$.

the mode of inheritance for the 9 SSR markers developed by Chen et al. (2008). The mode of inheritance of segregating loci was restricted to heterozygous parents' progeny array showing segregation at any particular locus after excluding those with offspring displaying segregation pattern similar to that of the maternal genotype. Individual parent's segregation analyses for heterozygous loci were analyzed using $G$-test of independence (Sokal and Rohlf, 1981) (not shown). When multiple trees shared the same genotype, replicated $G$-test of goodness-of-fit $\left(G_{P}\right)$ was conducted on the pooled segregation data (Sokal and Rohlf, 1981). Segregation data from multiple trees were also tested for heterogeneity using $G$-heterogeneity test $\left(G_{H}\right)$ (Sokal and Rohlf, 1981). In cases where significant $G_{P}$ and/or $G_{H}$ were observed, the cause of either the observed bias towards one allele or heterogeneity among segregating trees were investigated by comparing segregation mode at the individual tree level.

\subsection{Paternity and mating system analyses}

The revised likelihood-based paternity inference program CERVUS 3.0.3 (Marshall et al., 1998; Kalinowski et al., 2007) was used to assign the pollen donors for the 14 maternal seed donors' embryo pool. Since the maternal parents' multilocus genotypes were known, this paternity assignment was a partial pedigree reconstruction. The multilocus mixed-mating model of Ritland (2002) was used to estimate mating system parameters, including single-locus $\left(t_{s}\right)$ and multilocus $\left(t_{m}\right)$ outcrossing rates and multilocus correlated matings $\left(r_{p(m)}\right)$ using the Expectation-Maximization (EM) procedure of the computer program MLTR 3.1 (Ritland, 2002). Standard errors for mating system parameters were obtained from the construction of 1000 bootstrap replicates.

\subsection{Assessment of genetic gain and diversity}

Average breeding value (genetic gain: $\Delta G$ ) and male effective population size $\left(\sigma^{\top} N_{e}\right)$ were estimated as follows:

$$
\Delta G=\sum_{i=1}^{N} B V_{i} m_{i}
$$

and

$$
\sigma^{\top} N_{e}=\frac{1}{\sum_{i=1}^{N} m_{i}^{2}}
$$

where $N$ is the orchard's census number $(N=41)$, and $B V_{i}$ and $m_{i}$ denote the breeding value and the male gametic contribution of clone $i$, respectively $\left(0 \leq m_{i} \leq 1\right.$, and $\sum_{i=1}^{N} m_{i}=1$. The estimates of $\Delta G$ and $\sigma^{\top} N_{e}$ based on male gametic contributions obtained from the DNA analysis (i.e., pedigree reconstruction) were compared to those obtained from visual assessment of male reproductive output (Stoehr et al., 2004). Pollen contamination (gene flow) was not considered into the male effective population size calculation.

\section{RESULTS AND DISCUSSION}

\subsection{Microsatellite loci mode of inheritance}

The genotypes of parent trees were inferred from the segregation pattern of their offspring. The nine microsatellite markers tested produced 17 segregating allelic combinations, with six following the expected 1:1 segregation ratio, while the remaining 11 significantly deviated from either the expected 1:1 Mendelian inheritance and/or the $G$-heterogeneity 
test (Tab. I). The genotype of four seemingly "homozygous" parents was determined to be heterozygous with null alleles (UBCLXtet_2-12: Null/250 and Null/260, UBCLXdi_21: Null/315 and Null/335, and UBCLXdi_16: Null/240) (Tab. I). Homozygous parents' offspring should not segregate and the offspring banding pattern should be uniform and resembling the parental type (i.e., the parental band); however, the offspring of these four parents segregated and produced an excess of homozygous genotypes as well as genotypes that are characterized by no products (no amplifying bands) indicating the presence of null alleles in the parental genotypes, thus they are heterozygous with null allele (Tab. I). For example, at the UBCLXdi_16 locus, the two families produced a single band at 240 base-pair, thus they were originally genotyped as $240 / 240$; however, offspring segregation produced an excess of 240/240 homozygote as well as fewer individuals with no band. Additionally, the appearance of two other alleles ( 238 and 248 basepair) from the male side which resulted into one homozygous genotype of either $238 / 238$ or $248 / 248$ was also inductive of maternal null allele contribution, thus confirming the heterozygous genotype of the mother tree. This consistent pattern indicated that the parental genotypes should have been heterozygous for Null/240. Repeat scoring of the offspring of these two individuals supported this interpretation and yielded nonsignificant 1:1 segregation $(G$-test values of $=1.00(p=0.32)$ and $0.48(p=0.49))$ (not shown). Furthermore, the $G_{P}$ and $G_{H}$ goodness-of-fit tests of the pooled data of these two parents were non-significant (Tab. I). The same scenario was observed at the Null/250 and Null/260 genotypes at UBCLXtet_2-12 locus and Null/315 genotype at UBCLXdi_21 locus (Tab. I).

The segregation of the pooled data at UBCLXtet_2-12: Null/250 followed the expected 1:1 ratio; however, significant $G_{H}$ was observed, indicating the presence of different segregation patterns among mother trees (Tab. I). The majority of allelic combination deviated significantly from the 1:1 Mendelian expectation, in both pooled $\left(G_{P}\right)$ and heterogeneity $\left(G_{H}\right)$ tests (Tab. I). In most cases, deviations were mostly caused by the unexpectedly higher frequency of one allele over the other (e.g., allele 152 base-pair of UBCLXtet_2-11 locus) (Tab. I).

Segregation analysis of the 14 wind-pollinated progeny produced excessive departure from the expected 1:1 Mendelian mode of inheritance. This higher than expected segregation distortion could arise from inbreeding depression (Tani et al., 2004); however, both pedigree and mating system analyses indicated that inbreeding was minimal (see below). In fact we did not observe any evidence supporting heterozygote excess. We conducted a total of $51 G$-tests on individual progeny data, with only seven producing significant excess of heterozygosity with only two showing possible impact on the results of $G$-tests (result not shown). Segregation distortion can arise from many ways, such as residual heterozygosity in parental lines that resulted in complication of allelic assignment and difficult linkage determination (Cloutier et al., 1997), or a simple mutation occurring within the binding site for a DNA marker (Smith et al., 1997). Genetic analysis of PCR based marker depends on amplifying the variability in the length flanking with oligoprimers. Any mutation occur- ring within the DNA complementary to the oligoprimer may inhibit or completely prevent their binding, leading to an absence of PCR product. These "null" alleles will not necessarily be recognized when there is a product from the other homologue, and this may lead to an underestimate of marker heterozygosity and to apparent incompatibility of genotypes within a family. Null alleles have long been known for protein polymorphisms, VNTR (Variable Number of Tandem Repeats) markers (Chakraborty et al., 1992), microsatellite markers (Liewlaksaneeyanawin et al., 2002) and have been recognized, together with population subdivision, as a major factor in depression of observed heterozygosity, compared with that expected on the basis of Hardy-Weinberg equilibrium (Callen et al., 1993).

Microsatellite markers' null alleles were frequently observed in coniferous tree species with reported withinpopulation frequencies as high as 35\% (Pinus radiata: Fisher et al., 1998; Cryptomeria japonica: Moriguchi et al., 2003; Picea abies: Yazdani et al., 2003). Null alleles also varied among populations within species indicating that their presence is population-specific rather than species-pandemic (Tani et al., 2004). In the present study, significant presence of null alleles was observed at three primers (UBCLXdi-21, UBCLXtet_2-12, and UBCLXdi_16; Tab. I). Generally, the frequent presence of segregating null alleles found in microsatellite loci calls for some caution when using untested microsatellites as genetic markers, where underestimated heterozygosity and false parentage assignment could occur (Liewlaksaneeyanawin et al., 2002; Pemberton et al., 1995).

\subsection{Mating system analysis}

High single- $\left(t_{s}=85 \pm 0.023\right)$ and multi-locus $\left(t_{m}=\right.$ $97 \pm 0.013$ ) outcrossing rates were obtained from the 14-family array, indicating that outcrossing is predominant in this experimental population. Similar outcrossing rate estimates were observed in natural populations of the same species (El-Kassaby and Jaquish, 1996). Multi-locus correlated paternity $\left(\left(r_{p m}\right)\right.$; correlation of outcross paternity within progeny arrays) was low $(0.074 \pm 0.013)$, indicating the presence of multiple parents participating in pollination, and was similar to those reported in the species' natural populations (El-Kassaby and Jaquish, 1996). While the mating system analysis is informative, it falls short of providing an estimate of pollen migration to the orchard (contamination). El-Kassaby and Ritland (1986) highlighted the relationship between outcrossing rate and pollen migration and demonstrated that the higher the gene flow the higher the observed outcrossing, thus it should be stated that most seed orchards reported outcrossing rate estimates are inflated by gene flow. The multi-locus correlated paternity estimate also provided an indication of the correlation of outcross paternity within progeny arrays; however, it did not assess which males contributed to this estimate or the different male-female pollination success (Fig. 2). 
Table II. Summary of parentage analysis of 14 half-sib families with known mother genotypes at $95 \%$ confidence levels.

\begin{tabular}{|c|c|c|c|}
\hline \multirow[t]{2}{*}{ Parent ID } & \multirow[t]{2}{*}{ No. of full-sib groups } & \multicolumn{2}{|c|}{ No. of offspring } \\
\hline & & Assigned at $95 \%$ & Not assigned \\
\hline 3 & 15 & 26 & 14 \\
\hline 4 & 17 & 31 & 6 \\
\hline 7 & 13 & 29 & 11 \\
\hline 9 & 13 & 30 & 10 \\
\hline 14 & 18 & 31 & 7 \\
\hline 19 & 15 & 35 & 5 \\
\hline 20 & 15 & 34 & 6 \\
\hline 21 & 15 & 29 & 11 \\
\hline 24 & 18 & 31 & 8 \\
\hline 25 & 21 & 37 & 2 \\
\hline 30 & 22 & 34 & 6 \\
\hline 34 & 13 & 32 & 7 \\
\hline 39 & 14 & 26 & 14 \\
\hline 40 & 12 & 25 & 14 \\
\hline Total & 221 & 430 & 121 \\
\hline
\end{tabular}

\subsection{Paternity analysis}

A total of 430 out of $551(78 \%)$ embryos were assigned to one of the 41 potential male parents (Tab. II). Additionally a subset of 46 out of the assigned embryos were found to be the product of selfing (mating within tree or among ramets of the same clone) resulting into an estimate of outcrossing rate of $91.7 \%$, an intermediate value between the observed single$\left(t_{s}=85 \pm 0.023\right)$ and multi-locus $\left(t_{m}=97 \pm 0.013\right)$ outcrossing rates obtained from the mating system analysis (above). The observed variability between the two estimation methods (i.e., paternity vs. multilocus mixed-mating model) reflects the difference between the "exact" nature of paternity analysis and the estimation protocol of the mating system model that does not account for the presence of null alleles (i.e., offspring produced from gametes with null alleles are considered as the product of outcrossing even if they are originated from the same parent).

The remaining unassigned $121(22 \%)$ could be either the product of gene flow from the neighbouring orchard or their genotypes were not informative enough for assignment to any of the orchard's 41 parents (i.e., type II error (false exclusion) (Kalinowski et al., 2007; Oddou-Muratorio et al., 2003; Vandeputte et al., 2006)) or a combination of the two. It is also possible that some of the assigned embryos could be the product of type I error (false assignment) (Kalinowski et al., 2007; Oddou-Muratorio et al., 2003; Vandeputte et al., 2006); however, the set of embryos used for the mode of inheritance analyses were the same used in paternity analysis, thus it is unlikely that false assignment has a significant contribution. The number of unassigned embryos/female parent varied between 2 (Family 25) and 14 (Families 3, 39, and 40), this could be a function of female receptivity timing with outside pollen and/or the lack of informative nature of the embryos' genotypes (Tab. II).

The pedigree reconstruction produced 221 full-sib families nested within the 14 maternal half-sib families with a range of 12 (Family 40) to 22 (Family 30) full-sibs (Tab. II), indicating the effectiveness of pollination within the seed orchards (i.e., availability of many male parents for pollinating receptive females). The males' half-sib family size ranged between 0 (Families 29, 31, 37, 38) and 46 (Family 7) (Fig. 1), highlighting the effectiveness of spatial separation and randomization of ramets and clones within the seed orchard's grid that allowed tested parents' seed-cones to act as an effective pollen trap for providing an accurate assessment of pollination. Additionally, the slight observed variation among males' half-sib family sizes could also be caused by reproductive temporal separation (Fig. 1). The distribution of full-sib families and their size within and among parents varied and ranged between 1 and 8, with a large component of small size (1 to 3) (Fig. 2). This is expected considering the compactness of pollination season in interior British Columbia that is characterized by its abbreviated spring period caused by increased rate of accumulation of heat-sums over very short period of time (sudden shift from winter to summer seasons; El-Kassaby, personal observation) and the tested seed sample size of 40. Approximately 50,75 , and $90 \%$ of the within orchard's pollen pool was produced by the top $8(25 \%), 15(37 \%)$, and $25(61 \%)$ parents, respectively, and conversely, the remaining $10 \%$ was produced by the lowest 16 (39\%) parents. The use of SSR markers and paternity analysis confirmed the presence of male fertility variation within the studied seed orchard as reported, for instance, in Cryptomeria japonica (Moriguchi et al., 2004), Pseudotsuga menziesii (Slavov et al., 2005), and Prunus avium (Mariette et al., 2006), a difficult assessment to make based on pollen-cone count surveys which assume that reproductive energy is equal to reproductive success (Kang, 2000; Kang and Lindgren, 1998).

When the SSR-based observed male gametic contribution was used to estimate the within orchard male effective population size $\left(o^{\top} N_{e}\right)$, an estimate of 21 was produced. This value is significantly lower than the orchard's male census number of 41 or 33 (after considering variation in clone size). Similar results were also reported by Slavov et al. (2005) who studied male reproductive success in a Pseudotsuga menziesii seed orchard. The number of seeds fathered in their samples from a test block ranged from 1 to 17 , leading to a substantial decrease in the effective number of parents from 40 (the seed orchard's census number) to 20 (Slavov et al., 2005). In the present study, the impact of reduced male effective population size, estimated based on either DNA or male reproductive output assessment on genetic gain estimation was not substantial, yielding $\Delta G$ of 15 and 16 , respectively. We attribute this slight difference to the small range of breeding values among the orchard's clones (range: 10-26).

Knowledge of pollen dispersal within a seed orchard is essential for the development of new orchard designs and the development of effective management practices (Adams and Birkes, 1989; Wheeler et al., 1992). The identification of male parents' reproductive success is considerably more difficult 


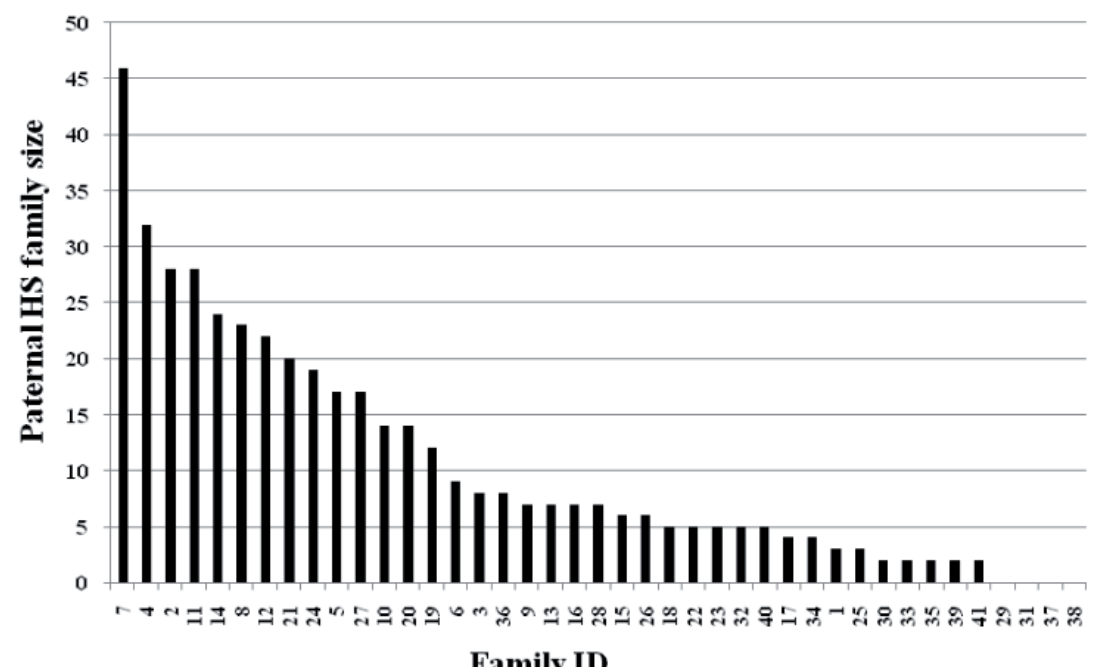

Figure 1. Paternal HS family size listed in a descending order.

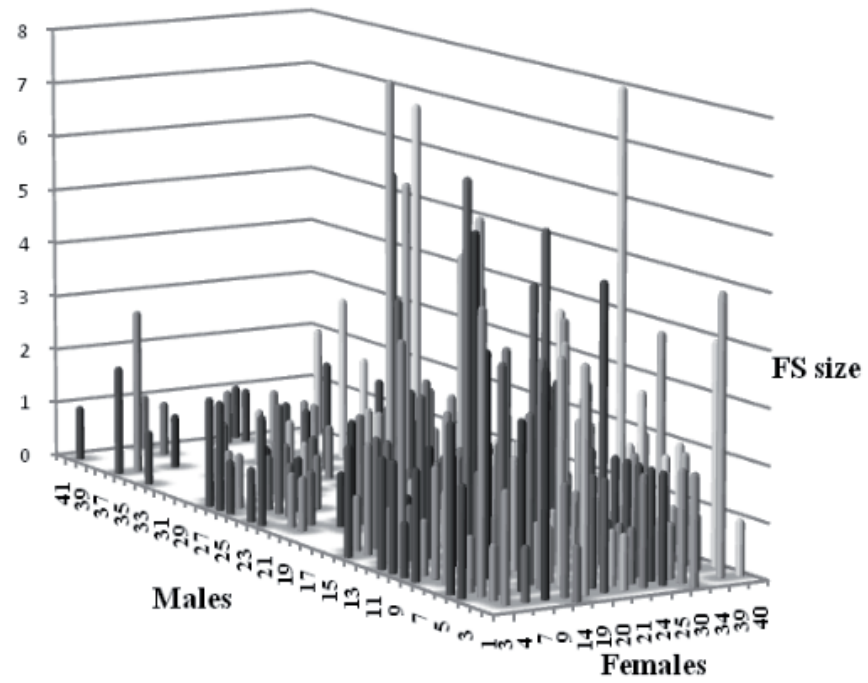

Figure 2. The distribution of 221 full-sib families from 14 wind-pollinated western larch seed donors.

(Devlin and Ellstrand, 1990). The measure of pollen movement is often tracked by the movement of pollinators, marker dyes (Linhart et al., 1987) or marked pollens (Greenwood, 1986; Levin and Kerster, 1969). These methods become impractical when large numbers of different pollinators are involved, the host plants are large or basically the number of the pollen resource is beyond manageable. Moreover, pollen dispersal based on directly measuring physical pollen movements may not always reflect actual fertilization and gene flow (reviewed in Dow and Ashley, 1998). Therefore, pollen dynamics/dispersal is best assessed directly using molecular markers (Brown, 1988). With the advantage of the high polymorphism of microsatellite markers, a high exclusion proba- bility can be provided owing to their co-dominant inheritance and high number of alleles.

In the present study, we demonstrated the usefulness of SSR markers in pedigree and mating analyses and identified 221 full-sib families within the studied 14 wind-pollinated (halfsib) families at a $95 \%$ confidence level. We have demonstrated the presence of male fertility variation resulting into fewer males successful siring the majority of the 14 studied female parents' offspring. In conclusion, the reported genetic evaluation of mating dynamics in the studied seed orchard would not have been possible without the use of informative markers such as SSRs and the recent theoretical development of paternity analysis. 
Acknowledgements: This work is support by the Natural Sciences and Engineering Research Council of Canada Discovery Grant and the Johnson's Family Forest Biotechnology Endowment to Y.A.E.

\section{REFERENCES}

Adams W.T. and Birkes D.S., 1989. Mating patterns in seed orchards. In: Proceeding of 20th Southern Forest Tree Improvement Conference, Charleston, South Carolina, pp. 75-86.

Bell G.D. and Fletcher A.M., 1978. Computer organized orchard layouts (COOL) based on the permutated neighbourhood design concept. Silvae Genet. 27: 223-225.

Brown A.H.D., 1988. Genetic characterization of plant mating system. In: Brown A.H.D., Clegg M.T., Kahler A.L., Weir B.S. (Eds.), Plant population genetics, breeding, and genetic resources. Sinauer Associates, Inc., Sunderland, Massachusetts, pp. 145-162.

Callen D.F., Thompson A.D., Shen Y., Phillips H.A., Richards R.I., Mulley J.C., and Sutherland G.R., 1993. Incidence and origin of "null" alleles in the (AC)n microsatellite markers. Am. J. Hum. Genet. 52: 922-927.

Chakraborty R., Andrade M.D., Daiger S.P., and Budowle B., 1992. Apparent heterozygote deficiencies observed in DNA typing data and their implications in forensic applications. Ann. Hum. Genet. 56: $45-57$.

Chen C.C., Liewlaksaneeyanawin C., Funda T., Kenawy A.M.A., Newton C.H., and El-Kassaby Y.A., 2008. Development and characterization of microsatellite loci in western larch (Larix occidentalis Nutt.). Mol. Ecol. Res. (in press).

Cloutier S., Cappadocia M., and Landry B.S., 1997. Analysis of RFLP mapping inaccuracy in Brassica napus L. Theor. Appl. Genet. 95: 83-91.

Devlin B. and Ellstrand N.C., 1990.The development and application of a refined method for estimating gene flow from angiosperm paternity analysis. Evolution 44: 248-259.

Dow B.D. and Ashley M.V., 1998. High levels of gene flow in bur oak revealed by paternity analysis using microsatellites. J. Hered. 89: $62-70$.

Doyle J.J. and Doyle J.L., 1990. Isolation of plant DNA from fresh tissue. Focus 12: 13-15.

El-Kassaby Y.A. and Jaquish B., 1996. Population density and mating pattern in western larch. J.Hered. 87: 438-443.

El-Kassaby Y.A. and Ritland K., 1986. The relation of outcrossing and contamination to reproductive phenology and supplemental mass pollination in a Douglas-fir seed orchard. Silvae Genet. 35: 240-244.

Faulkner R., 1975. Seed orchards. Forestry Commission. Bulletin No. 54, $149 \mathrm{p}$.

Fins L. and Seeb L.W., 1986. Genetic variation in allozymes of western larch. Can. J. For. Res. 16: 1013-1018.

Fisher P.J., Richardson T.E., and Gardner R.C., 1998. Characteristics of single- and multi-copy microsatellites from Pinus radiata. Theor. Appl. Genet. 96: 969-979.

Forest Genetics Council of BC, 2008. Business plan. Woods J.H. (compiler and Ed.), ISSN 1498-1378.

Greenwood M.S., 1986. Gene exchange in loblolly pine: the relation between pollination mechanism, female receptivity and pollen availability. Am. J. Bot. 73: 1443-1451.

Jaquish B. and El-Kassaby Y.A., 1998. Genetic variation of western larch in British Columbia and its conservation. J. Hered. 89: 248-253.
Jaquish B., Howe G.T., Fins L., and Rust M., 1995. Western larch tree improvement programs in the inland empire and British Columbia. In: Schmidt W.C., McDonald K.J. (Eds.), Ecology and management of Larix forests: a look ahead. USDA Forest Service, Intermountain Research Satation Technical Report,GTR-INT 319.

Jones A.G. and Ardren W.R., 2003. Methods of parentage analysis in natural populations. Mol. Ecol. 12: 2511-2523.

Kalinowski S.T., Taper M.L., and Marshall T.C., 2007. Revising how the computer program CERVUS accommodates genotyping error increases success in paternity assignment. Mol. Ecol. 16: 1099-1106.

Kang K.-S., 2000. Clonal and annual variation of flower production and composition of gamete gene pool in a clonal seed orchard of Pinus densiflora. Can. J. For. Res. 30: 1275-1280.

Kang K.-S. and Lindgren D., 1998. Fertility variation and its effects on the relatedness of seeds in Pinus densiflora, Pinus thunbergii and Pinus koraiensis clonal seed orchards. Silvae Genet. 47: 196-201.

Khasa P.D., Newton C.H., Rahman M.H., Jaquish B., and Dancik B.P., 2000. Isolation, characterization, and inheritance of microsatellite loci in alpine larch and western larch. Genome 43: 439-448.

Levin D.A. and Kerster H.W., 1969. The dependence of bee-mediated pollen and gene dispersal upon plant diversity. Evolution 23: 560571.

Liewlaksaneeyanawin C., Ritland C.E., and El-Kassaby Y.A., 2002. Inheritance of null alleles for microsatellites in the white pine weevil (Pissodes strobi (Peck), (Coleoptera: Curculionidae)). J. Hered. 93: 67-70.

Linhart Y.B., Busby W.H., Beach J.H., and Feinsinger P., 1987. Forager behavior, pollen dispersal and inbreeding in two species of hummingbird-pollinated plants. Evolution 41: 679-682.

Mariette S., Balsemin E., Stoeckel S., Tavaud M., Le Boler H., Santi F., and Verger M., 2007. Parental participation in progeny and effective population sizes in experimental seed orchards of wild cherry Prunus avium L. (Batsch). Ann. For. Sci. 64: 533-539.

Marshall T.C., Slate J., Kruuk L.E.B., and Pemberton J.M., 1998. Statistical confidence for likelihood-based paternity inference in natural populations. Mol. Ecol. 7: 639-655.

Moriguchi Y., Iwata H., Ihara T., Yoshimura K., Taira H., and Tsumura Y., 2003. Development and characterization of microsatellite markers for Cryptomeria japonica D. Don. Theor. Appl. Genet. 106: 751758.

Moriguchi Y., Taira H., Tani N., and Tsumura Y., 2004. Variation of paternal contribution in a seed orchard of Cryptomeria japonica determined using microsatellite markers. Can. J. For. Res. 34: 1683-1690.

Oddou-Muratorio S., Houot M.-L., Demesure-Musch B., and Austerlitz F., Pollen flow in the wildservice tree, Sorbus torminalis (L.) Crantz. I. Evaluating the paternity analysis procedure in continuous populations. Mol. Ecol. 12: 3427-3439.

Pemberton J.M., Slate J., Bancroft D.R., and Barrett J.A., 1995. Nonamplifying alleles at microsatellite loci: a caution for parentage and population studies. Mol. Ecol. 4: 1670-1677.

Ritland K., 2002. Extensions of models for the estimation of mating system using $\mathrm{n}$ indpendent loci. Heredity 88 : 221-228.

Schmidt W.C., 1995. Around the world with Larix: an introduction. In: Schmidt W.C., McDonald K.J. (Eds.), Ecology and management of Larix forests: a look ahead. USDA Forest Service, Intermountain Research Satation Technical Report, GTR-INT 319.

Schmidt W.C. and McDonald K.J., 1995. Ecology and management of Larix forests: a look ahead. USDA Forest Service, Intermountain Research Station General Technical Report, GTR-INT-319.

Schmidt W.C. and Shearer R.C., 1995. Larix occidentalis: a pioneer of the North American west. In: Schmidt W.C. and McDonald K.J. (Eds.), Ecology and management of Larix forests: a look ahead. USDA Forest Service, Intermountain Research Satation Technical Report, GTR-INT 319. 
Schmidt W.C., Shearer R.C., and Roe A.L., 1976. Ecology and silviculture of western larch forests. USDA Forest Service, Washington, DC, USA.

Semerikov V.L. and Lascoux M., 1999. Genetic relationships among Eurasian and American Larix species based on allozymes. Heredity 83: $62-70$

Semerikov V.L. and Matveev A.V., 1995. Investigation of genetic variation of isozyme loci in Siberian larch, Larix sibirica Ldb. Russ. J. Genet. 31: 944-949.

Semerikov V.L., Semerikov L.F., and Lascoux M., 1999. Intra- and interspecific allozyme variability in Eurasian Larix Mill. species. Heredity 82: 193-204.

Slavov G.T., Howe G.T., and Adams W.T., 2005. Pollen contamination and mating patterns in a Douglas-fir seed orchard as measured by simple sequence repeat markers. Can. J. For. Res. 35: 1592-1603.

Smith J.S.C., Chin E.C.L., Shu H., Smith O.S., Wall S.J., Senior M.L., Mitchell S.E., Kresovich S., and Ziegle J., 1997. An evaluation of the utility of SSR loci as molecular markers in maize (Zea mays L.): comparisons with data from RFLPS and pedigree. Theor. Appl. Genet. 95: 163-173.

Sokal R.R. and Rohlf F.J., 1981. Biometry. 2nd ed. W.H. Freeman and Co., New York.
Stoehr M., Webber J., and Woods J., 2004. Protocol for rating seed orchard seedlots in British Columbia: quantifying genetic gain and diversity. Forestry 77: 297-303.

Tani N., Takahashi T., Ujino-Ihara T., Iwata H., Yoshimura K., and Tusumura Y., 2004. Development and characteristics of microsatellite markers for sugi (Cryptomeria japonica D. Don) derived from microsatellite-enriched libraries. Ann. For. Sci. 61: 569-575.

Vandeputte S., Mauger S., and Dupont-Nivet M., 2006. An evaluation of allowing for mismatches as a way to manage genotyping errors in parentage assignment by exclusion. Mol. Ecol. Notes 6: 265-267.

Vendramin G.G. and Hansen O.K., 2005. Molecular markers for characterizing diversity in forest trees. In: Geburek T., Turok, J. (Eds.). Conservation and management of forest genetic resources in Europe. Arbora Publishers, Zvolen, Slovakia, pp. 337-368.

Wheeler N.C., Adams W.T., and Hamrick J.L., 1992. Pollen distribution in wind-pollinated seed orchards. In: Bramlett D.L., Askew G.R., Blush T.D., Bridgwater F.E., Jett J.B. (Eds.), Pollen Management Handbook. USDA Forest Service Agriculture Bulletin.

Yazdani R., Scotti I., Jansson G., Plomion C., and Mathur G., 2003. Inheritance and diversity of simple sequence repeat (SSR) microsatellite markers in various families of Picea abies. Hereditas 138: 219-227. 